
\title{
25 Research Square \\ Implementation of Foodcare a Hospital Nutritional Care Concept: A Pilot Study
}

\section{Nanna Møller Lykkegaard Rasmussen}

Hospitalsenheden Vest

Alexander Erichsen

Hospitalsenheden Vest

Allan Stubbe Christensen

Hospitalsenheden Vest

Kirstine Guld Frederiksen

Hospitalsenheden Vest

\section{Signe Loftager Okkels ( $\sim$ sigokk@rm.dk)}

Department of Clinical Nutrition Regional Hospital West Jutland, Gødstrup Hospital Lægårdsvej 12 7500 Holstebro Denmark

\section{Lone Viggers}

Hospitalsenheden Vest

\section{Research}

Keywords: A la carte, hospital food, nutritional risk, undernutrition, protein intake, energy intake

Posted Date: December 3rd, 2020

DOI: https://doi.org/10.21203/rs.3.rs-118281/v1

License: (c) (i) This work is licensed under a Creative Commons Attribution 4.0 International License.

Read Full License 


\section{Abstract}

Background: Different attempts have been made to improve nutritional care and food intake in hospital inpatients. One way may be to improve the individual customisation of meals and meal time points. This pilot study compared the food concept FoodCare consisting of customised meals served on demand and standardised meals served at fixed time points concerning energy and protein intake in medical inpatients.

Method: A pilot study including medical lung inpatients at a Danish regional hospital. The control group received a set menu with limited choices served at fixed times. The intervention group received a menu of customised dishes prepared by food professionals and served on demand.

Results: Twelve patients were included in the control group and 26 patients in the intervention group. In the intervention group, the tendency showed an increased energy ( $8.8 \pm 2.7 \mathrm{MJ}$ (mean $\pm \mathrm{SD}$ ) compared with the control group of $7.3 \pm 2.0 \mathrm{MJ}, \mathrm{p}=0.10$ ) and protein intake ( $74 \pm 26$ grams compared with the control group of $60 \pm 18$ (mean $\pm S D$ ) grams, $p=0.08$ ).

Conclusion: This pilot study demonstrated that a self-selected menu served on demand may potentially increase energy and protein intake in medical inpatients. The concept should be further tested in a randomised control trial with a sufficient sample size.

\section{Background}

Due to the widespread status of undernutrition among patients in hospital, it is of critical importance to study inpatient meals and nutrition. It has been shown that 30 to $60 \%$ of patients with chronic obstructive pulmonary disease (COPD) suffer from undernutrition [1] and approximately $40 \%$ of lung patients experience an unintended weight loss during hospitalisation [2]. Furthermore, patients' nutritional status often deteriorates during hospitalisation [3]. Undernutrition has a multifactorial aetiology and is associated with increased morbidity, mortality, length of hospital stay, infection rate and decreased quality of life $[3,4]$. Many patients are challenged to meet nutritional requirements both due to personal issues and problems in the dining room surroundings. Factors responsible for not meeting nutritional requirements could be loss of appetite [5], fixed meal timing, limited individual choice and access to snacks [6]. Furthermore, undernutrition has serious socio-economic consequences. A Dutch study from 2011 estimated that the total additional annual costs of managing adult patients with disease-related malnutrition were estimated to 1.9 billion Euro [7]. A good nutritional status has a positive effect on quality of life [8]. The current catering system at Regional Hospital West Jutland (RHW) in Denmark consists of a buffet. The general impression from meetings with the staff from various clinical departments is that the patients are satisfied with the food [9]. However, an internal audit from 2019 revealed that $50 \%$ of the patients lost weight during their hospitalisation [9]. Thus, the patients do not eat the recommended amount of food. In general, it is estimated that between 20 and $50 \%$ of hospitalised patients are undernourished $[6,10]$. Furthermore, only around $30 \%$ of the patients obtained their minimum 
requirement of protein $[10,11]$. Different interventions have been initiated to improve the nutritional status of patients such as protein enriched in-between-meals [6] and improved sensory aspects of meals [11]. A review found that serving meals more frequently could also be a way to improve food consumption among hospitalised patients [12]. To counteract weight loss, an improved energy and protein intake is important [12]. One way to combat these problems could be to enhance the nutritional effort giving individual meal preferences more attention. Danish studies by Freil [10] and Munk [11] showed that introducing hospital catering where patients could freely choose meals from a menu had a positive effect on energy and protein intake.

At RHW, a new catering concept "Food Service and Nutrition Care" (FoodCare) has been introduced. This nutritional model combines food and meals tailored to the patients' specific health conditions and aims at ensuring nutritional therapy to all relevant inpatients following the a la carte principle and served to patients on demand. Thus, FoodCare is intended to provide all inpatients with nutritious food and meals to optimise treatment, recovery and health. The FoodCare concept also includes nutritional support by a registered dietitian. This pilot study investigated whether FoodCare improved nutritional status in hospitalised patients with pulmonary diseases.

\section{Methods}

\section{Study design and population}

The study was designed as an intervention pilot study with two arms. Patients in the control group comprised inpatients from a medical ward of pulmonary diseases at RHW. The control phase took place within a period of three weeks (from 25 January to 12 February 2016). Patients in the intervention group were recruited from the same ward in a period of four weeks (from 22 February to 18 March 2016). The time periods were fixed, and inclusion entirely depended on the overall patient flow in the time periods as well as patients' ability and willingness to participate. All patients admitted to the ward underwent nutritional screening by a registered dietitian who was also responsible for recruitment.

Patients were eligible to participate in the study if they (1): were able to understand the purpose of the study; (2): had an intact gastrointestinal function; (3): had an anticipated length of hospitalisation of three days or more; (4): were able to understand and speak Danish.

Exclusion criteria were (1): terminal illness; (2): dementia; or (3): a diet based exclusively on artificial nutrition.

Oral and written information was given and written informed consent was obtained from patients before inclusion. The study protocol was approved by the Danish Data Protection Agency.

\section{Menus and meal ordering}

The FoodCare Food Service concept 
In the intervention group, the patients received the new food concept FoodCare and based on an a la carte principle where patients order appetizing dishes from a menu from 7.30 am to $8.00 \mathrm{pm}$ served on demand.

At admission, all patients received a FoodCare menu, and a nurse or registered dietitian introduced the patient to the food concept. Each day of hospitalisation, the patient was free to order as many meals as he/she wanted at any time. Patients who were bedridden had their meals ordered by nurses or hospital cook in the ward kitchen. The patients who were able to walk to the kitchen ordered the meals there. Hospital cooks prepared the food in the kitchen, and meals were served within 30 minutes in the dining room or in the patient room according to the wish of the patient. Bedridden patients had their food served in bed. The registered dietitian and hospital cooks were at the ward every day from 7 am to $9 \mathrm{pm}$. The registered dietitian suggested different types of in-between meals snacks for the patient. The menu in the new food concept was based on patient preferences and experiences from kitchen staff and registered dietitians. The menu consisted of different types of sandwiches, rye bread with cold cuts, cold refreshments, soups, porridges, warm dishes, snacks, cold and warm beverages (Table 1). The menu described and showed the meals patients could choose. The nutritional content in these meals focused on meals with a naturally high protein and energy content. When required, the patients received oral nutritional supplements. Initially, the hospital cooks and chefs from the central hospital kitchen received training in the new food concept and methods. A guide including visual material on how to arrange and serve the food was developed to ensure standardisation and high quality of the individual dishes. Further, nursing staff was trained in the study concept at staff meetings. At these meetings it was highlighted that patients were free to order their meals at any time during the day in the intervention period.

\section{The traditional Food Service concept}

In the control group, patients received a set buffet menu served at fixed times (breakfast 7.30 am, lunch $11.45 \mathrm{am}$, dinner $6.00 \mathrm{pm}$ ). Additionally, in-between meals were offered (e.g. biscuits, cake, ice cream, fruits, and dessert mousses). The nurses were responsible for prescribing diet and ordering the food for bedridden patients; all other patients ordered the food themselves. Service assistants handed the food from the buffet to caregivers or patients. An overview of the intervention and control group can be seen in Figure 1.

\section{Outcomes}

\section{Nutritional requirements}

At inclusion, a registered dietitian estimated the patient's energy and protein requirements using the Harris-Benedict equation, which includes the patient's sex, age, weight and height [14]. The estimated basic metabolic rate was multiplied by an activity factor and a stress factor according to the patient's level of physical activity and severity of disease. Protein requirements were calculated according to recommendations for chronically ill patients (1.2-1.5 gram/kg body weight) [15]. We used $1.4 \mathrm{gram} / \mathrm{kg}$ body weight as a pragmatic solution to accommodate the needs of the patient group in this study. In 
patients with a body mass index (BMI) above $27 \mathrm{~kg} / \mathrm{m}^{2}$, the weight at BMI $27 \mathrm{~kg} / \mathrm{m}^{2}$ was used to estimate both energy and protein requirements.

\section{Food intake}

In the control group, nurses and patients registered breakfast and snacks and later validated by a registered dietitian. Intake at lunch and dinner was documented by a registered dietitian by taking photos of the plate before and after the meal. Afterwards, two independent registered dietitians using pictures to estimate reference portions for comparison. If needed, they reconstructed the plate with the real meal elements and performed an actual measurement of the intake.

In the intervention group, intake was registered in collaboration between the patient, nurse, and registered dietitian. The registered dietitian had the overall responsibility for ensuring completion and verification of the dietary records. In the intervention group, the portion size was standardised and therefore documentation by photos was not needed.

On the basis of these dietary records, energy and protein intake was calculated using the DankostPro (version 2.17, Kraftvaerk Group, Copenhagen). The registrations of food intake were noted at days 2, 3 and 4 of hospitalisation. However, some patients were not admitted to the ward for more than two or three days and food intake was thus only registered for this period. The mean intake of both energy and protein during the registration period was calculated for each patient.

\section{Nutritional screening}

Nutritional screening was performed by nurses in the control group and by registered dietitians in the intervention group. In both groups, the nutritional screening tool "NRS-2002" for hospital inpatients was used [13]. First, the primary screening was performed to evaluate the patient's nutritional status. If the patient was at nutritional risk, a secondary screening was performed. In the secondary screening, nutritional status, severity of disease and age were evaluated. If the nutritional score is $\geq 3$ the patient is at nutritional risk and a nutritional (care) plan should be initiated. If the score is $<3$ weekly screenings should be made to monitor nutritional status.

\section{Statistical analysis}

Statistical analyses were performed using STATA, version 14.1 (StataCorp, Texas, USA). Since data were normally distributed, statistical differences between the groups were tested by the Students' t-test for continuous data and Fisher's exact test for categorical data. Furthermore, mean, standard deviation (SD) and percentages were used for descriptive purposes. Results were presented as mean \pm SD unless otherwise stated. All statistical tests and $p$-values were two-sided and a $p<0.05$ was considered statistically significant.

\section{Results}


Twelve patients were included in the control group and 26 patients in the intervention group. Characteristics of sex, age, weight, BMI and diagnoses in the two groups are presented in Table 2. There were no significant differences between the groups, although there was an almost significant difference between the age of patients the two groups. The most frequent diagnosis was chronic obstructive pulmonary disease (COPD). Patients diagnosed with pneumonia, cancer, asthma, and dyspnoea were also included.

\section{Nutritional intake}

Table 3 shows the energy and protein intake of the two group. The mean energy intake was higher $(p=0.10)$ in the intervention group compared to the control group, $8.8 \pm 2.7$ and $7.3 \pm 2.0 \mathrm{MJ}$, respectively (Figure 2). Similarly, the mean protein intake was higher in the intervention group compared to the control group ( $p=0.08$ ), $74 \pm 26$ and $60 \pm 18$ gram, respectively (Figure 3 ).

\section{Nutritional screening}

Table 3 shows nutritional risk assessment in the control and intervention group. In the control group, ten patients underwent primary nutritional screening; five were screened within 24 hours of admission. In the secondary screening, three patients had a NRS score $\geq 3$ and one patient scored $<3$. In two patients, the secondary screening was not performed. In the intervention group 23 patients underwent primary nutritional screening and 17 of these were within 24 hours of admission. In the secondary screening, 16 patients had a NRS score $\geq 3$ and one patient scored $<3$. Two patients did not have the secondary screening.

\section{Discussion}

This pilot study demonstrated that the new food concept FoodCare may potentially increase energy and protein intake in medical inpatients with pulmonary diseases.

\section{Food intake}

In our pilot study, we wanted to study the effect of meal variation from a variety of different menu choices, which patients could choose freely at any time of the day compared to a control group receiving standardised meals served at fixed time points. Our results showed there was a tendency to both increased protein and energy intake in the intervention group. This increase could be the effect of the meal variation and the choice that the patient was offered. Previously, two Danish studies have shown that offering patients a variation of protein-enriched meals increased their energy and protein intake [10, 11]. In these studies, a variety of high protein meals were offered at different time points to allow patients to shape his own daily menu. We did not use protein-enriched meals, but we selected dishes with a relatively high natural content of energy and protein. Further, in our study and the above-mentioned two studies, there were no fixed meal times. A fixed menu at fixed time points is the ordinary way of meal serving at RHW and most other hospitals. When the patient is given autonomy to choose his/her meal, the patient becomes an active part in the hospitalisation. In a survey at an English hospital with 41 
patients, the factor of free choice of meals was found to be an important factor in improving hospital food services [16]. Although patients in the traditional Food Service concept in theory are offered three inbetween meals a day, we know from clinical experience that this rarely happens. Thus, another explanation for the gain in energy and protein in the intervention compared to the control group could be that the intervention group were offered more in-between meals. This was also reported in a recent Danish study, where improved focus on in-between meals also improved energy and protein intake [6].

\section{Patient autonomy}

One of the major strengths of the new food concept was that the patient had the opportunity to eat anytime during the day. When the patient has the free choice to eat a meal anytime he/she wants to eat, it has been seen that patient satisfaction is increasing [24] and in another study the use of a digital decision support system was reducing the proportion of malnourished patients [25]. This could probably be related to the autonomy that is given to the patient. Hospitals seldom gives possibilities to make individual meal choices [16]. In a group of nursing home residents in Sweden, it was found that the participants wished to have the possibility to decide the menu [17]. Furthermore, a higher degree of participation in the practical aspects of the meal was warranted [17]. Each day, the patients of the current pilot study were free to shape their own menu. The increased patient autonomy in our study where patients in the intervention group could design their own menu could explain the tendency of an increased protein and energy intake in this group. A meal intervention supporting patient autonomy and giving the patient an informed choice is a very effective way of creating a higher participant satisfaction and acceptance. This effect has also been found to increase food intake in a study including orthopedic inpatients [18]. The same association was also found in a questionnaire survey in a group of Swiss patients [19] and a qualitative survey made in Swedish nursing home residents [17]. The participants from the Swiss study had to choose their meals from a variety of food choices. Further, in the same study it was found that meals should be visualized in a food plan to give the patient the possibility to make a more informed and well-founded choice [19].

\section{Strengths And Limitations}

The statistical power of our pilot study was low. We saw a clinically relevant increase in the intervention group of energy $(1.5 \mathrm{MJ})$ and protein intake (14 gram). A statistical difference in protein and energy intake was found between the intervention and control groups in three comparable studies [13, 20, 21]. In our pilot study, the difference between protein and energy intake in the two groups was not statistically different but similar (or even higher) compared to the above mentioned three studies [13,20,21]. Due to agreements and time restraints of this pilot study it was unfortunately not possible to include more patients. Difficulties obtaining a large sample with a high patient number have previously been found in nutritional intervention studies including both old adults and patients $[22,23]$. We were aware of the importance of involving both the patients and staff as much in the project as possible to create a higher participation and a lower dropout rate [23]. The difference between age in the two groups was almost statistically significant. However, it did not seem to affect the main results when performing a sensitivity 
analysis (data not shown). In the intervention group more patients had a NRS score $\geq 3$, which indicates that a stronger effort was needed to positively influence the energy and protein intake of these patients.

\section{Future perspectives}

It could be interesting to investigate the effects of the nutritional intervention in a future randomized controlled study including a bigger sample. Further, it could also be interesting to apply a patient-oriented focus to investigate patients' perceptions, opinions, feelings and emotions towards the new food concept using a qualitative design, which has been used in a Dutch meal study [26].

\section{Conclusion}

The intervention group of this pilot study shaped their own menu choosing between a variety of meals from a menu and meals were served on demand. The intervention group in this study had a clinically relevant, though not statistically significant, increase in their energy and protein intake. Thus, a selfselected menu served on demand may potentially increase the energy and protein intake in medical inpatients. It is recommended to repeat the pilot study in a larger sample to test the validity of the results.

\section{Declarations}

\section{Acknowledgments}

We thank all the patients participating in our study as well as the staff from the Department of Lung Diseases, Department of Clinical Nutrition and NIDO | Danmark for their collaboration and for making this project possible.

\section{Authors' contributions}

Christensen, A. S., Erichsen, A., Frederiksen, K. G., and Viggers, L. contributed to the study design. Christensen, A. S. and Erichsen, A. provided the statistical analysis. Rasmussen, N. M. L. collected the data and drafted the manuscript in cooperation with Christensen, A. S. and Okkels, S. L. All authors have contributed to the revision of the manuscript and have read and approved the final manuscript submitted for publication.

\section{Funding}

The study was internally funded by the Department of Clinical Nutrition, Regional Hospital West Jutland, Gødstrup Hospital, Denmark.

\section{Availability of data and materials}

Upon reasonable request the datasets are available from the corresponding author.

\section{Ethics approval and consent to participate}

Oral and written information was given and written informed consent was obtained from patients before inclusion. The study protocol was approved by the Danish Data Protection Agency. 


\section{Consent for publication}

Not applicable

\section{Competing interest}

All authors declare that they have no conflicts of interest.

\section{References}

1. Nielsen, M., Stassen, I. T, Strømstad, G. V. (In Danish). Klinisk retningslinje for ernæring til indlagte patienter med KOL. Aalborg University Denmark 2015. Center for kliniske retningslinjer.

2. Chailleux, E., Laaban, J. P., Veale, D. Prognostic value of nutritional depletion in patients with COPD treated by long-term oxygen therapy: data from the ANTADIR observatory. Chest Journal 2003; 123 : 1460-1466.

3. Geiker, N. R. W., Larsen, S. M. H., Stender, S \& Astrup, A. Nutritional screening: Phlebotomist rounds to collect lifestyle factors in newly hospitalized patients; results available in laboratory reports: A feasibility trial. e-SPEN 2012; 7(6) pp. e229-e233.

4. Stratton, R. J., Green, C. J., Elia, M. Disease-Related Malnutrition: An Evidence- Based Approach to Treatment. 2003. CABI Publishing, Wallingford, United Kingdom

5. Blundell, J., de Graaf, C., Hulshof, T., Jebb, S., Livingstone, B., Lluch, A., Mela, D., Salah, S., Schuring, E., van der Knaap, H., Westerterp, M. Appetite control: methodological aspects of the evaluation of foods. Obesity reviews 2010; 11(3): 251- 270.

6. Mortensen, M. N., Larsen, A. K., Skadhauge, L. B., Høgsted, R. H., Beermann, T., Cook, M. E., Rasmussen, H. H., Mikkelsen, B. E., Holst, M. Protein and energy intake improved by in-between meals: An intervention study in hospitalized patients. Clinical Nutrition ESPEN 2019; 30: 113-118.

7. Freijer, K., Tan, S. S., Koopmanschap, M. A., Meijers, J. M. M., Halfens, R. J. G., Nuijten, M. J. C., The economic costs of disease related malnutrition. Clinical Nutrition 2013; 32: 136-141.

8. Volkert, D., Beck, A. M., Cederholm, T., Cruz-Jentoft, A., Goisser, S., Hooper, L., Kiesswetter, E., Marcello, M., Maggio, Raynaud-Simon, A., Sieber, C. C., Sobotka, L., van Asselt, D., Wirth, R., Bischoff, S. C., ESPEN guideline on clinical nutrition and hydration in geriatrics. Clinical Nutrition ESPEN 2018: 1-38. In Press.

9. Viggers, L., Nutrition Manager, The Nutrition Unit, Holstebro and Herning hospital. Email: Lone.Viggers@vest.rm.dk. Personal communication at a meeting 24.03.2020.

10. Freil, M., Nielsen, M. A., Bitz, C., Gut, R., Mikkelsen, B. E., Almdal, T. Reorganization of a hospital catering system increases food intake in patients with inadequate intake. Scandinavian Journal of Food and Nutrition 2005; 50(2): 83-88.

11. Munk, T., Beck, A. M., Holst, M., Rosenbom, E., Rasmussen, H. H., Nielsen, M. A., Thomsen, T. Positive effect of protein-supplemented hospital food on protein intake in patients at nutritional risk: a randomized controlled trial. Clinical Nutrition 2014; 27: 122-132. 
12. Uzogara, S. G. Underweight, the Less Discussed Type of Unhealthy Weight and Its Implications: A Review. American Journal of Food Science and Nutrition Research 2016(5): 126-142.

13. Kondrup, J., Rasmussen, H. H., Hamberg, O., Stanga, Z., Ad hoc ESPEN working group. Nutritional risk screening (NRS 2002): a new method based on an analysis of controlled clinical trials. Clinical nutrition 2003; 22(3): 321-336.

14. Sobotka, L. 2012. Basics in clinical nutrition. Galen 4th edition.

15. Raimondo, M. \& Scolapio, J. S. Nutrition in pancreatic disorders. In: Modern Nutrition in Health and Disease, 10th edn. eds M. E. Shils, M. Shike, A.C. Ross, B. Caballero \& R.J. Cousins. 2006. Philadelphia, PA: Lippincott Williams \& Wilkens. 1227-1233.

16. Johns, N., Hartwell, H., Morgan, M. Improving the provision of meals in hospital. The patients' viewpoint. Appetite 2010; 54: 181-185.

17. Odencrants, S., Blomberg, K., Wallin, A. The meal is an activity involving at least two people. Experiences of meals by older persons in need of elderly care. Nursing Open 2019; 7(1): 265-273.

18. Price R. J. G., Mcmurdo, M. E. T., Anderson, A. S. A personalized snack-based intervention for hip fracture patients: development, feasibility and acceptability. Journal of Human Nutrition and Dietetics 2006; 19(2):139e45.

19. Stanga, Z., Zurflüh, Y., Roselli, M., Sterchi, A. B., Tanner, B. Knecht, G., Hospital Food: A Survey of Patients' Perceptions. Clinical Nutrition 2003. 22(3):241-6.

20. Munk, T., Bruun, N., Nielsen, M. A., Thomsen, T. From evidence to clinical Practice: Positive effect of implementing a protein-enriched hospital menu in conjunction with individualized dietary counseling. Nutrition in Clinical Practice. 2017. 32: 420-426.

21. Dijxhoorn, D. N., van den Berg, M. G. A., Kievit, W., Korzilius, J., Drenth, J, P. H., Wanten, G. J. A. A novel in-hospital meal service improves protein and energy intake. Clinical Nutrition. 2018. 37: 2238-2245.

22. Beelen, J., de Roos, N. M., de Groot, L. C. P. G. M. Protein enrichment of familiar foods as an innovative strategy to increase protein intake in institutionalized elderly. Journal of Nutrition Health Aging 2017; 21(2): 173-179.

23. Beck, A. M., Damkjær, K., Tetens, I. Lack of compliance of staff in an intervention study with focus on nutrition, exercise and oral care among old $(65+\mathrm{yrs})$. Danish nursing home residents. Aging clinical and experimental research 2009; 21(2): 143-149.

24. Doorduijn, A. S., Gameren, Y., v., Vasse, E., de Roos, N. M. At your request ${ }^{\circledR}$ room service dining improves patient satisfaction, maintains nutritional status, and offers opportunities to improve intake. Clinical Nutrition: 2016. 35: 1174-1180.

25. Paulsen, M. M., Paur, I., Gjestland, J., Henriksen, C., Varsi, C., Tangvik, R. J., Andersen, L. F., Effects of using the MyFood decision support system on hospitalized patients' nutritional status and treatment: A randomized controlled trial. Clinical Nutrition: 2020. In Press.

26. den Uijl, L., C., Jager, G., de Graaf, C., Waddell, J., Kremer, S. It is not just a meal, it is an emotional experience - A segmentation of older persons based on the emotions that they associate with 
mealtimes. Appetite: 2014. 83: 287-296.

\section{Tables}

Table 1. A selection of some of the meals in the menu of FoodCare.

\begin{tabular}{|c|c|c|c|}
\hline Brunch & Cold meals & Warm meals & $\begin{array}{l}\text { Soups and } \\
\text { porridges }\end{array}$ \\
\hline Rye bread with soft kernels & $\begin{array}{l}\text { Small dish with } \\
\text { shrimps, } \\
\text { mayonnaise } \\
\text { and eggs }\end{array}$ & $\begin{array}{l}\text { Warm liver paté } \\
\text { with crispy bacon } \\
\text { and pickled beets }\end{array}$ & $\begin{array}{l}\text { Rye bread } \\
\text { soup with } \\
\text { cold whipped } \\
\text { cream or milk }\end{array}$ \\
\hline Breakfast rolls (light or whole grain) & $\begin{array}{l}\text { old-style } \\
\text { marinated } \\
\text { herring with } \\
\text { curry in mayo } \\
\text { and rye bread }\end{array}$ & $\begin{array}{l}\text { Crispy vegetable } \\
\text { gratin with bacon }\end{array}$ & $\begin{array}{l}\text { Rice porridge } \\
\text { with cold } \\
\text { butter and } \\
\text { cinnamon } \\
\text { sugar }\end{array}$ \\
\hline White bread (light or whole grain) & $\begin{array}{l}\text { Small dish with } \\
\text { chicken in } \\
\text { mayo, } \\
\text { pineapple and } \\
\text { bacon }\end{array}$ & $\begin{array}{l}\text { Tartlet with creamy } \\
\text { chicken and } \\
\text { asparagus sauce }\end{array}$ & $\begin{array}{l}\text { Homemade } \\
\text { clear soup } \\
\text { with } \\
\text { meatballs } \\
\text { and } \\
\text { dumplings }\end{array}$ \\
\hline $\begin{array}{l}\text { Homemade cold cuts, soft organic } \\
\text { cheese, homemade jam, cream cheese, } \\
\text { honey, scrambled eggs and bacon, soft } \\
\text { boiled egg, sour milk, cereals. }\end{array}$ & $\begin{array}{l}\text { Rye bread with } \\
\text { homemade } \\
\text { roast beef }\end{array}$ & $\begin{array}{l}\text { Homemade } \\
\text { meatballs with } \\
\text { cranberries, gravy } \\
\text { sauce and white } \\
\text { potatoes }\end{array}$ & $\begin{array}{l}\text { Creamy soup } \\
\text { of asparagus } \\
\text { with } \\
\text { meatballs }\end{array}$ \\
\hline
\end{tabular}

Table 2: Characteristics of patients in control and intervention group.

* = Pearsons chi-squared test, $\uparrow=$ Fishers exact test. 


\begin{tabular}{|llll|}
\hline & Control N=12 & Intervention N=26 & p-value \\
\hline Sex, N (\%) & $4(34)$ & $9(35)$ & 0.62 * \\
Male & $8(67)$ & $17(65)$ & \\
Female & & & \\
Age (mean \pm SD) & $61 \pm 16$ & $72 \pm 15$ & $0.05+$ \\
Weight (mean \pm SD) & $65 \pm 14$ & $68 \pm 15$ & $0.54+$ \\
BMI (mean \pm SD) & $23 \pm 4$ & $24 \pm 4$ & $0.56+$ \\
Main diagnoses, N (\%) & $7(58)$ & $18(69)$ & - \\
COPD & $3(25)$ & $4(15)$ & - \\
Cneumonia & $1(8)$ & $2(8)$ & - \\
Asthma & $1(8)$ & $1(4)$ & - \\
Dyspnoea & 0 & $1(4)$ & \\
\hline
\end{tabular}

Table 3: Nutritional risk assessment in control and intervention group. ${ }^{*}=\mathrm{T}$-test, $\boldsymbol{\dagger}=$ Fishers exact test.

\begin{tabular}{|llll|}
\hline & $\begin{array}{l}\text { Control group, } \\
\mathrm{N}=12\end{array}$ & $\begin{array}{l}\text { Intervention group, } \\
\mathrm{N}=26\end{array}$ & P-value \\
\hline Average Energy intake (Mean $\pm \mathrm{SD})$ & $7.3 \pm 2.0 \mathrm{MJ}$ & $8.8 \pm 2.6 \mathrm{MJ}$ & 0.10 * \\
\hline Average Protein intake (Mean $\pm \mathrm{SD})$ & $60 \pm 18 \mathrm{~g}$ & $74 \pm 26 \mathrm{~g}$ & 0.08 * \\
\hline Primary nutritional screening & $\mathrm{N}(\%)$ & $\mathrm{N}(\%)$ & \\
\hline $\begin{array}{l}\text { Primary nutritional screening } \\
\text { None }\end{array}$ & $2(17)$ & $3(12)$ & \\
\hline $\begin{array}{l}\text { Primary nutritional screening } \\
\text { Made within 24 h from initial admission }\end{array}$ & $5(41.5)$ & $17(65)$ & 0.335 † \\
\hline $\begin{array}{l}\text { Primary nutritional screening made } \\
\text { After 24 h from initial admission }\end{array}$ & $5(41.5)$ & $6(23)$ & \\
\hline Secondary nutritional screening & Total sample: 6 & Total sample: 19 & \\
\hline No & $\mathrm{N}(\%)$ & $\mathrm{N}(\%)$ & \\
\hline$<3$ points & $2(33)$ & $2(11)$ & 0.125 † \\
\hline$\geq 3$ points & $1(17)$ & $1(5)$ & \\
\hline
\end{tabular}




\section{Figures}

\section{Intervention group}

- Individual menu - Foodcare. Patients order meals from a menu card. The meals were served on demand during the day (from 7AM to 21PM) and served maximum 30 min after ordering.

- The food intake were registered on paper

\section{Control group}

- Fixed menu

- Fixed meal times at 7.30AM, 11.45AM and 18PM.

Furthermore in between-meals were offerred.

Figure 1

overview of the menus and meal times in the intervention and control group.

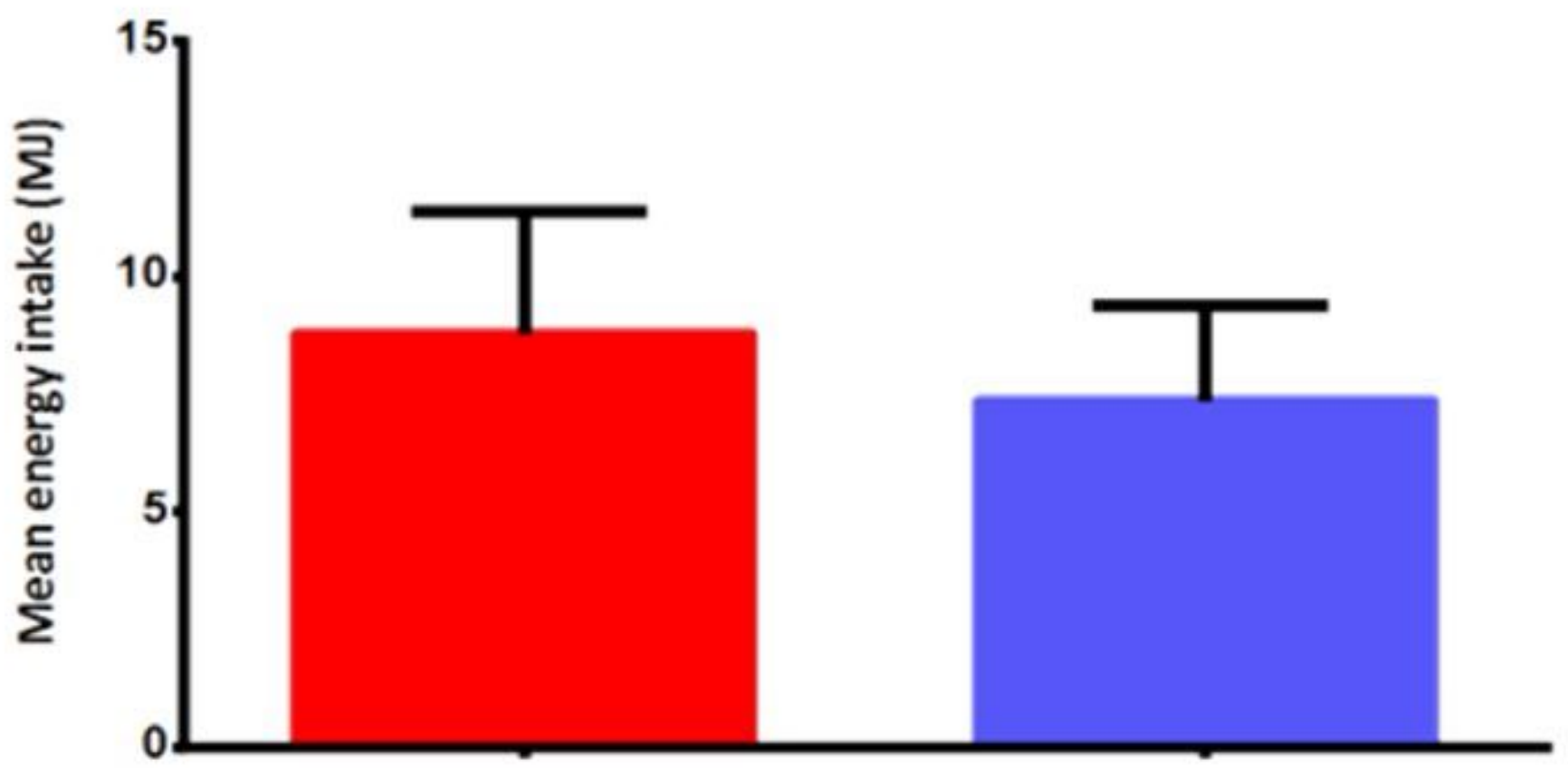

Intervention group

Control group 
Figure 2

Mean energy intake plus SD (Megajoule) in the intervention and control group

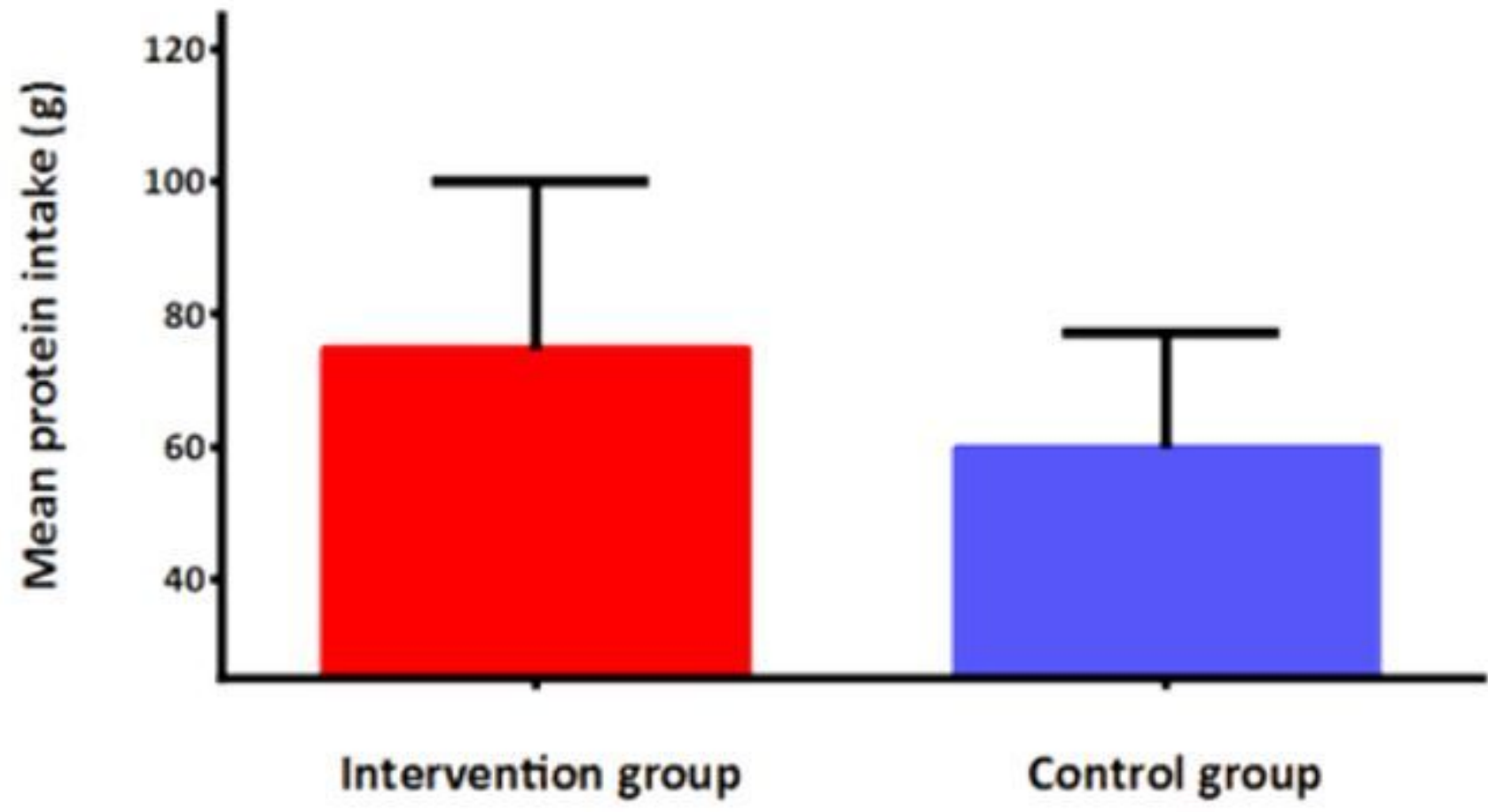

Figure 3

Mean protein intake plus SD (gram) in the intervention and control group 